\title{
Cytotoxicity of derivatives of oncocalyxone A from Auxemma oncocalyx Taub
}

\author{
Cláudia Pessoa, ${ }^{1 *}$ Telma L.G. Lemos, ${ }^{2}$ Otília D.L. Pessoa, ${ }^{2}$ Manoel O. Moraes, ${ }^{1}$ Denissa \\ Vasconcellos, ${ }^{1}$ Letícia V. Costa-Lotufo, ${ }^{1}$ and Albert Leyva ${ }^{3}$ \\ ${ }^{1}$ Departamento de Fisiologia e Farmacologia, Universidade Federal do Ceará, Caixa Postal \\ 3157, 60430-970, Fortaleza, CE, Brasil. ${ }^{2}$ Departamento de Química Orgânica e Inorgânica \\ Universidade Federal do Ceará, Caixa Postal 12200, 60021-940, Fortaleza, CE, Brasil ${ }^{3}$ \\ Department of Pharmacology, University of Missouri, Kansas City, 2411 Holmes, Kansas City, \\ MO 64108
}

E-mail: cpessoa@ufc.br

\section{Dedicated to Professor Otto Richard Gottlieb on his $85^{\text {th }}$ birthday}

(received 24 Nov 04; accepted 30 July 04; published on the web 05 Aug 04)

\begin{abstract}
Oncocalyxone A (1) (rel-8 $\alpha$-hydroxy-5-hydroxymethyl-2-methoxy-8aß-methyl-7,8,8a,9tetrahydro-1,4-anthracenedione) is a 1,4-anthracenedione that has been shown to be cytotoxic to human tumor cells and to be DNA reactive. Three derivatives of 1 obtained by chlorination (6chloro-oncocalyxone A, 2) and acetylation (11-O-acetyloncocalyxone A, 3; 8,11-Odiacetyloncocalyxone A, 4) were found to be less cytotoxic and less DNA reactive in human leukemia cells. These derivatives were less polar compounds with modifications that may have hindered binding of the compound to DNA.
\end{abstract}

Keywords: Oncocalyxone A, cytotoxicity, anthracenedione, Auxemma oncocalyx, natural products

\section{Introduction}

In an earlier paper, we reported on the in vitro cytotoxicity of several compounds isolated from plants commonly used in Brazilian traditional medicine ${ }^{1}$. One of the most potent compounds was a 1,4-anthracenedione isolated from Auxemma oncocalyx (Boraginaceae) ${ }^{2}$, a common tree found only in Ceará state, Brazil ${ }^{3}$. The ethanol extract of the heartwood yields rel-8 $\alpha$-hydroxy-5hydroxymethyl -2 -methoxy - 8a $\beta$-methyl -7,8,8a,9 -tetrahydro-1,4-anthracenedi- one, given the common name oncocalyxone A (Figure 1). Cytotoxicity was demonstrated in vitro in a panel of human cancer cell lines with $\mathrm{IC}_{50}$ values ranging 1-18 $\mu \mathrm{g} / \mathrm{mL}$. Oncocalyxone A was most toxic to CEM leukemia cells and caused DNA damage. However, its potency is still relatively 
low compared with related anthraquinone anticancer drugs. ${ }^{4}$ Recently, a series of oncocalyxone A derivatives were prepared using catalytic hydrogenation, chlorination, acetylation, epoxidation and methylation. ${ }^{5}$ Three of these derivatives were compared to the parent compound with respect to inhibition of tumor cell growth and to DNA reactivity.

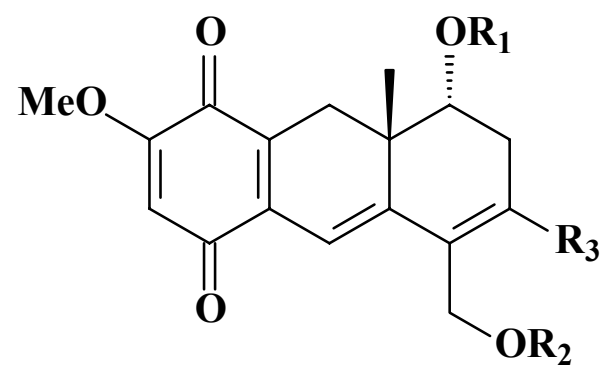

1: $\mathrm{R}_{1}=\mathrm{R}_{2}=\mathrm{R}_{3}=\mathrm{H}$

2: $\mathrm{R}_{1}=\mathrm{R}_{2}=\mathrm{H} ; \mathrm{R}_{3}=\mathrm{Cl}$

3: $R_{1}=H ; R_{2}=A c ; R_{3}=H$

4: $\mathrm{R}_{1}=\mathrm{R}_{2}=\mathrm{Ac} ; \mathrm{R}_{3}=\mathrm{H}$

Figure 1. Chemical structure of Oncocalyxone A 1 (rel-8 $\alpha$-hydroxy-5-hydroxymethyl-2methoxy-8aß-methyl-7,8,8a,9-tetrahydro-1,4-anthracenedione) and its derivatives: 6-chlorooncocalyxone A, 2 (rel - 6 - chloro - 8 - hydroxy - 5 - hydroxymethyl - 8a $\beta$ - methyl - 2 methoxy - 7,8,8a,9 - tetrahydro- 1,4- anthracenedione), 11-O-acetyl-oncocalyxone A, 3 (rel - 5 acetoxymethyl - $8 \alpha$ - hydroxy - 8a $\beta$ - methyl - 2 - methoxy- 7,8,8a,9 - tetrahydro - 1,4anthracenedione), and 8,11-O-diacetyl-oncocalyxone A, 4 (rel - 8 $\alpha$ - acetoxy - 5- acetoxymethyl - 8aß - methyl - 2 - methoxy - 7,8,8a,9 - tetrahydro - 1,4 - anthracenedione).

\section{Results and Discussion}

Oncocalyxone A (1) and three derivatives 6-chloro-oncocalyxone A (2), 8-acetyloncocalyxone A (3) and 8,11-diacetyl-oncocalyxone A (4) were tested for cytotoxicity in CEM leukemia cells and SW1573 lung tumor cells by the MTT assay.

Table 1 shows that in leukemia cells derivatives $\mathbf{2}$ and $\mathbf{4}$, but not $\mathbf{3}$, were significantly less active than the parent compound with $\mathrm{IC}_{50}$ values more than 2-fold higher. All four compounds caused cell kill as well as cell growth-inhibition at concentrations above $5 \mu \mathrm{g} / \mathrm{mL}$ in CEM, as evidenced by changes in cell morphology and complete loss of cellular MTT reductive activity (not shown). Moreover, the three derivatives as well as compound $\mathbf{1}$ produced significant $(p<$ 0.01) DNA damage in CEM at a concentration of $5 \mu \mathrm{g} / \mathrm{mL}$ (Figure 2). However, at a concentration of $2 \mu \mathrm{g} / \mathrm{mL}$ that produced partial cell kill, only 1 caused significant $(p<0.05)$ DNA damage (Figure 2). The three derivatives when tested for cytotoxicity in SW1573 lung tumor cells showed no significant differences. 
Table 1. Cytotoxic effects of the 1,4-anthracenedione oncocalyxone A and its derivatives

\begin{tabular}{lcc}
\hline Compounds & \multicolumn{2}{c}{$\mathrm{IC}_{50} *(\mu \mathrm{g} / \mathrm{mL}$, mean \pm S.D $)$} \\
& $\mathrm{CEM}$ & $\mathrm{SW} 1573$ \\
\hline Oncocalyxone A (1) & $1.4 \pm 0.5$ & $4.9 \pm 1.5$ \\
6-Chloro-oncocalyxone A (2) & $3.3 \pm 0.7 * *$ & $4.7 \pm 0.1$ \\
8-O-Acetyl-oncocalyxone A (3) & $2.0 \pm 0.2$ & $3.3 \pm 0.4$ \\
8,11-O-Diacetyl-oncocalyxone A (4) & $3.5 \pm 1.3 * *$ & $5.2 \pm 0.2$ \\
\hline
\end{tabular}

* Concentration inhibiting 50\% cell growth. $* * p<0.05$ ANOVA followed by Student Newman Keuls.

A

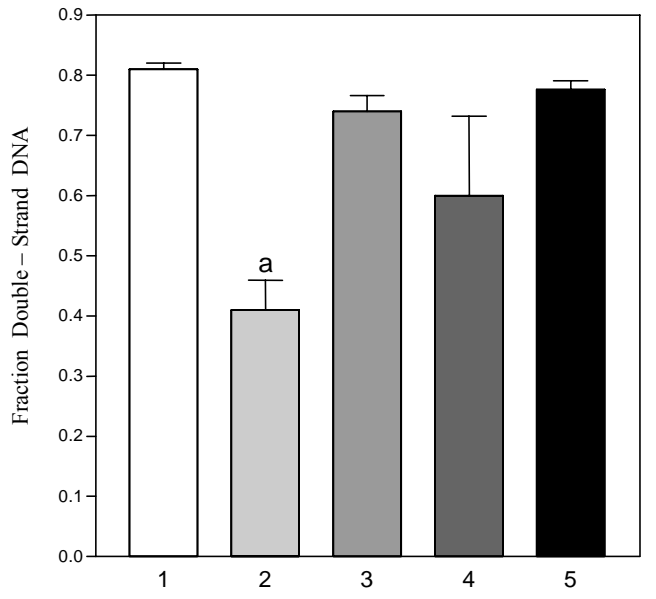

$\mathrm{B}$

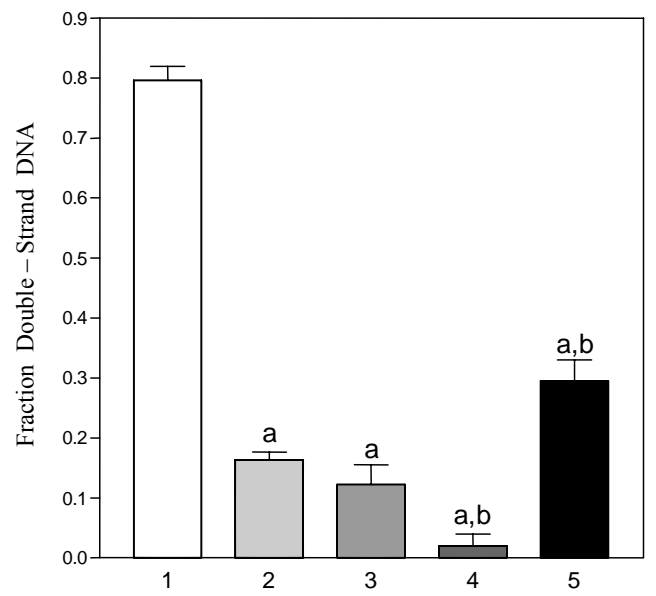

Figure 2. DNA damage in CEM leukemia cells by 1,4-anthracenediones at $2 \mu \mathrm{g} / \mathrm{mL}(\mathrm{A})$ and $5 \mu \mathrm{g} / \mathrm{mL}$ (B) concentrations. $1=$ control; $2=$ oncocalyxone A; $3=6$-chloro-oncocalyxone A; $4=$ 8-O-acetyl-oncocalyxone A; $5=8,11$-O-diacetyl-oncocalyxone A. a, $\mathrm{p}<0.01$ as compared to control and $\mathrm{b}, \mathrm{p}<0.01$ as compared to oncocalyxone A by ANOVA followed by Student Newman Keuls.

Based on both inhibition of cell growth and DNA damage, two of the three derivatives of oncocalyxone A showed diminished bioactivity, which could have been due to reduced DNA intercalating activity. Oncocalyxone A consists of a planar, polycyclic, aromatic ring complex, an essential feature of all DNA intercalating agents. Unlike the clinically active, anticancer anthraquinones, including doxorubicin and mitoxantrone, oncocalyxone A lacks an amino sugar or aminoalkylamino side chain. These latter groups enhance DNA binding through electrostatic binding with phosphate groups. ${ }^{6}$ The hydroxyl groups on the A ring of doxorubicin or mitoxantrone are also important for the electrostatic interaction with the ribose moieties of DNA. Notably, the non-hydroxylated analog of mitoxantrone was shown to be much less active than mitoxantrone. ${ }^{7}$ Similarly, the hydroxyl groups at C-8 or C-11 of oncocalyxone A may also be involved in DNA binding activity through hydrogen bonding, since their acetylation reduces bioactivity. In 2 the chlorine at C-6 with a partial negative charge could alter hydrogen bonding 
with the hydroxyl group at $\mathrm{C}-11$, thereby competing with electrostatic interaction with DNA ribose moieties. Decreased DNA intercalating activity would reduce DNA damaging effects through single and double strand breaks. The equal cytotoxicity of the derivatives compared to the parent compound in the lung tumor cells indicates that such modest structural changes may produce changes in differential cytotoxicity. The latter needs to be examined further in several different tumor cell lines, since it may have an impact on selectivity of cytotoxic effect one cell type versus another. Oncocalyxone A (1) represents a novel class of anthraquinones isolated from higher plants that is cytotoxic to tumor cells in vitro. Further investigations of these 1,4anthracenediones are needed to determine their potential as antitumor agents.

\section{Experimental Section}

Test compounds. Oncocalyxone A (1) is a wine red pigment isolated in good yield from Auxemma oncocalyx, an endemic tree of the state of Ceará, Brazil. The preparation, purification, and the chemical identification by spectral data are described elsewhere. ${ }^{2,5}$ Compounds were dissolved in DMSO at $5 \mathrm{mg} / \mathrm{mL}$ concentration before dilution in cell culture medium.

Oncocalyxone A [rel-8a-hydroxy-5-hydroxymethyl-8aß-methyl-2-methoxy-7,8,8a,9-tetrahydro-1,4anthracenedione] (1). m.p. $209-211{ }^{\circ} \mathrm{C}$. IR (KBr) cm${ }^{-1}$ : 3430, 3380, 1645, 1625, 1570, 1485, 970, 845. EIMS m/z, $70 \mathrm{eV}(\%): 302\left(\mathrm{M}^{+}, 50\right), 284(41), 171(22), 128(31), 115(31) .{ }^{1} \mathrm{H}$ and ${ }^{13} \mathrm{C}$ NMR (200 and $50 \mathrm{MHz}$ respectively, DMSO- $\mathrm{d}_{6}$ ) data were in agreement with literature. ${ }^{5}$

6-Chloro-oncocalyxone A [rel - 6 - chloro - 8 $\alpha$ - hydroxy - 5 - hydroxymethyl - 8a $\beta$ - methyl - 2 - methoxy - 7,8,8a,9 - tetrahydro- 1,4- anthracenedione] (2). m.p. $112-114{ }^{\circ} \mathrm{C}$. IR $(\mathrm{KBr}) \mathrm{cm}^{-1}$ : 3400, 1646, 1536. EIMS m/z, $70 \mathrm{eV}(\%): 338\left(\mathrm{M}^{+}, 14\right), 320(1), 305(18), 289(23) .{ }^{1} \mathrm{H}$ and ${ }^{13} \mathrm{C}$ NMR (200 and $50 \mathrm{MHz}$ respectively, $\mathrm{CDCl}_{3}$ ) data were in agreement with literature. ${ }^{5}$

11 - $O$ - Acetyl - oncocalyxone A [rel - 5 - acetoxymethyl - 8a - hydroxy - 8a - methyl - 2 methoxy- 7,8,8a,9 - tetrahydro - 1,4- anthracenedione] (3). m.p. $77-79{ }^{\circ} \mathrm{C}$. IR (KBr) cm ${ }^{-1}$ : 3455, 1736, 1235. EIMS m/z, $70 \mathrm{eV}(\%): 344\left(\mathrm{M}^{+}, 23\right), 284$ (51), $225(100) .{ }^{1} \mathrm{H}$ and ${ }^{13} \mathrm{C}$ NMR (200 and $50 \mathrm{MHz}$ respectively, $\mathrm{CDCl}_{3}$ ) data were in agreement with literature. ${ }^{5}$

8,11 - $O$ - Diacetyl - oncocalyxone A [rel - 8 $\alpha$ - acetoxy - 5- acetoxymethyl - 8a $\beta$ - methyl - 2 - methoxy - 7,8,8a,9 - tetrahydro - 1,4 - anthracenedione] (4). m.p. $173-176{ }^{\circ} \mathrm{C}$. IR (KBr) cm

${ }^{1}: 1738,1651,2236,1029 .{ }^{1} \mathrm{H}$ and ${ }^{13} \mathrm{C}$ NMR $\left(200\right.$ and $50 \mathrm{MHz}$ respectively, $\mathrm{CDCl}_{3}$ ) data were in agreement with literature. $^{2}$

Cell lines. Two human tumor cells lines were used for determination of cytotoxicity screening: CEM leukemia were obtained from the ATCC and SW1573 lung tumor cells were obtained from Dr. H. Broxterman (Free University, Amstertam, Netherlands). Cells were maintained in RPMI1640 medium supplemented with 10\% fetal bovine serum and 25 mM HEPES buffer (J.R.H. Biosciences, Lenexa, KS) and passaged twice a week to keep cells in rapid growth phase. CEM cells were grown as stationary suspension cultures and diluted for passaging, while SW573 cells 
grew as monolayers and were first trypsinized before passaging. All cultures were maintained at $37^{\circ} \mathrm{C}$ in $5 \% \mathrm{CO}_{2}$ atmosphere. The viability of either cell line was greater than $95 \%$ as determined by trypan blue exclusion.

MTT assay. The test compounds were examined for antiproliferative or cytotoxic continuous drug exposure, as described previously ${ }^{1,8}$. CEM cultures were diluted with fresh medium to $5 \mathrm{x}$ $10^{5}$ cells $/ \mathrm{mL}$ and plated in 96-well microplates at $100 \mu \mathrm{L} /$ well. After a $3 \mathrm{hr}$ re-equilibration period, $100 \mu \mathrm{L}$ of test sample was added to each well. SW1573 cells were plated at 2000 cells $/ 100 \mu \mathrm{L} /$ well and allowed to adhere and re-equilibrate overnight before addition of test samples. The test compounds were serially diluted 1:2 in culture medium and $100 \mu \mathrm{L}$ amounts were added to microplates. The cells were incubated for $72 \mathrm{hr}$, the medium was removed, and $200 \mu \mathrm{L}$ fresh medium with $0.5 \mathrm{mg} / \mathrm{mL}$ MTT was added. After $3 \mathrm{hr}$ further incubation the MTT formazan product was dissolved with DMSO and the absorbance was read on a Flow Multiskan plate reader at $570 \mathrm{~nm}$. All sample concentrations were tested in three replicate wells for each plate, and in at least three separate experiments.

DNA damage. DNA damage was determined in CEM cells based on the partial alkaline unwinding of DNA assay using fluorometric detection as described earlier ${ }^{1,9}$. Briefly, CEM cultures at $5 \times 10^{5}$ cells $/ \mathrm{mL}$ were treated with test substance for $24 \mathrm{hr}$. Cells were resuspended in phosphate-buffered saline ( $\mathrm{pH} 7.5)$ and exposed to non-denaturing or partially denaturing (0.05 $\mathrm{N} \mathrm{NaOH}$ for $30 \mathrm{~min}$ ) conditions, and then treated with $1 \mu \mathrm{g} / \mathrm{mL}$ bisbenzimide. Differential fluorescence of bisbenzimide bound to double- or single-stranded DNA was measured at $353 \mathrm{~nm}$ excitation and $451 \mathrm{~nm}$ emission.

Statistical test. The mean \pm S.E.M. were obtained from $\mathrm{n}$ independent experiments. The $\mathrm{IC}_{50}$ was obtained by non-linear regression using the GRAPHPAD program (Intuitive Software for Science, San Diego, CA). The differences between experimental groups were compared by oneway analysis of variance (ANOVA) followed by Student Newman Keuls.

\section{Acknowledgements}

We are grateful for the financial support from grants from the Brazilian science foundations CAPES, FINEP and CNPq. We also thank the Laboratory Clementino Fraga, Fortaleza for the use of their facilities when needed.

\section{References}

1. Pessoa, C.; Silveira, E. R.; Lemos, T. L. G.; Wetmore, L. A.; Moraes, M. O.; Leyva. A. Phytother. Res. 2000, 14, 187.

2. Pessoa, O. D. L.; Lemos, T. L. G.; Silveira, E. R.; Braz-Filho, R. Nat. Prod. Lett. 1993, 2, 145. 
3. Braga, R. Plantas do Nordeste, Especialemente do Ceara; $2^{\text {nd }}$ Edn.; Editora Universitária, Coleção Mossoroense: Natal, RN, Brazil, 1976.

4. Leyva, A.; Pessoa, C.; Boogaerdt, F.; Sokaroski, R.; Lemos, T. L. G.; Wetmore, L.A.; Huruta, R.; Moraes, M. O. Anticancer Res. 2000, 20, 1029.

5. Marques, W. B.; Pessoa, O. D. L.; Lemos, T. L. G.; Braz-Filho R. Rev. Latinoamer. Quím. 2000, 28, 111.

6. Steward C. F.; Ratain, M. J. In Cancer Principles \& Practice of Oncology; $5^{\text {th }}$ Edn, DeVita, V. T.; Hellman, Jr., S.; Rosenberg, S.A., Eds.; Lippencott-Raven, Philadelphia, 1997, 452.

7. Brown J. R. In Molecular Aspects of Anti-cancer Drug Action; Neidle, S.; Waring, M. J. Eds.; The Macmillan Press Ltd.: London, 1983, p 57.

8. Pieters, R.; Huismans, D. R.; Leyva, A.; Veerman, A. J. P. Cancer Lett. 1988, 41, 323.

9. Kanter P. M.; Schwartz H. S. Mol. Pharmacol. 1983, 22, 145. 